INFONORTH $• 541$

\title{
Interactive Effects of Environmental Conditions and Contaminants on Incubation Behaviour in an Arctic Seabird
}

by Reyd Smith

\section{INTRODUCTION}

I NCREASED HUMAN ACTIVITY IN RECENT DECADES has resulted in widespread abiotic environmental shifts that affect many ecosystem dynamics (IPCC, 2019). These shifts include rising air and ocean temperatures (Scavia et al., 2002; Pörtner and Peck, 2010), changes in wind and ocean circulation (Hayward, 1997), a reduction of sea ice (Johannessen et al., 2004; Hoegh-Guldberg and Bruno, 2010; IPCC, 2019), and an elevated release of contaminants into the environment including harmful metals such as mercury (Dietz et al., 2009; Liu et al., 2012). Due to these extreme human-driven changes in recent years, Arctic systems in particular are increasingly impacted by these stressors that show amplification in Arctic regions (Serreze and Barry, 2011; Descamps et al., 2017; Serreze and Meier, 2018). These changes influence a multitude of ecosystem and population dynamics including food web characteristics such as prey availability and selection (Frederiksen et al., 2006), as well as individual reproductive success and survival (Bustnes et al., 2001; Visser et al., 2009; Durant et al., 2010; Nord and Nilsson, 2011; Tartu et al., 2016). Importantly, a combined exposure to multiple stressors concurrently, such as contaminants and climate change, is expected to cause amplified impacts on individuals, however, is an area requiring more investigation. My research examines the potential interactive effects of varied temperature and wind exposure, in combination with mercury levels, on the incubation behaviour of Common Eider (Somateria mollissima) at Mitivik (East Bay Island), Southampton Island, Nunavut.

\section{Mercury as an Endocrine Disrupting Contaminant}

Contaminant concentrations are increasing in the Arctic through long-range transport towards the poles by air, oceans, and food-web interactions, influencing many aspects of Arctic life (Macdonald et al., 2000; Pratte et al., 2015). Arctic marine environments are particularly at risk of elevated contaminants transport and biomagnification in marine food webs (Macdonald et al., 2000; Jæger et al., 2009). One contaminant in particular, mercury, is stored in animal tissues at higher levels than is found in the environment (Wiener et al., 2003) and is found elevated in higher trophic levels as it is one of few metals that biomagnifies throughout food webs (Campbell et al., 2005). Mercury is distributed around the globe by means of oceanic and atmospheric currents, as well as through integration into food web dynamics, where it is accumulated by individuals and can interfere with neurological, endocrine, and reproductive systems (Bustnes et al., 2001; Ottinger et al., 2015; Pratte et al., 2015). Although mercury is found naturally in the environment through processes such as volcanic eruptions, half of the mercury currently found in the environment stems from anthropogenic sources (Liu et al., 2012) where it is discharged in increasingly large amounts through industrial processes (Dietz et al., 2009) that release approximately 5000 tons of mercury into the environment annually (Liu et al., 2012). While North American and European emissions are decreasing, the global decrease is being slowed as other countries are contributing increasing amounts (Zhang et al., 2015; Zhang et al., 2016).

Mercury has been shown to have a large diversity of effects across multiple vertebrate taxa (Muir et al., 1992; Colborn et al., 1993). In birds, mercury has been shown to have widespread adverse effects on many aspects of behaviour, neurology, physiology, and reproduction (Boening, 2000; Seewagen, 2010). For example, elevated mercury levels have been correlated with decreases in the likeliness to breed in Black-legged Kittiwakes (Rissa tridactyla) (Tartu et al., 2013). Mechanistically, these mercury-related reductions in breeding propensity have been linked with reductions in key reproductive hormones, such as luteinizing hormone, which is involved in the subsequent release of sex hormones (i.e., estrogens) and therefore successful growth of gonadal tissues (Tartu et al., 2013). Studies have also indicated that elevated mercury can impact later stages of breeding in birds, such as incubation behaviour via decreased incubation consistency (i.e. increased on and off bout duration) and decreased incubation temperatures (Bustnes et al., 2001; Fisher et al., 2006). These effects are potentially mediated by the impacts of contaminants such as mercury on prolactin (PRL), a hormone involved in parental egg and chick attachment (Tartu et al., 2016). Mercury has already been shown to impair reproductive performance by disrupting PRL secretion in Arctic Black-legged Kittiwakes (Tartu et al., 2016).

\section{Climate Change Induced Increases in Ambient Temperature in the Arctic}

Climate change is impacting Arctic regions through alterations in sea ice cover, increased frequency, severity and unpredictability of weather systems, as well as elevated ambient temperatures reaching almost twice the global average (Descamps et al., 2017; Serreze and Meier, 2018). These alterations in environmental conditions occur notably in Arctic systems because of short breeding 
seasons at extreme latitudes as well as differences in annual prey production (Martin and Wiebe, 2004). In addition, given the current rapid rate of change, Arctic species may no longer be as proficient at adapting to and anticipating the sometimes severe inter-annual climactic variability (Stempniewicz, et al., 2007; Ceia and Ramos, 2015).

Human-induced climate change has resulted in rising ambient temperature trends and greater temperature extremes globally in recent decades (Meehl et al., 2000). These shifts in climate patterns are indirectly impacting higher trophic level species via profound alterations to trophic dynamics (Frederiksen et al., 2006), ocean chemistry (Solomon et al., 2009), changes in predator regimes (Smith et al., 2010; Iverson et al., 2014; Prop et al., 2015), and mismatch in phenology of organisms (Crick, 2004; Descamps et al., 2017). Importantly, elevated ambient temperatures have been shown to directly impact avian reproduction through advancement of lay dates in songbird species (Visser et al., 2009), along with accelerated incubation periods and embryonic growth (Nord and Nilsson, 2011; Durant et al., 2010), and even decreased incubation attentiveness (Martin and Camfield, 2009). In addition, birds that are exposed to less wind during incubation due to nest shelter installation have been shown to have a reduced incubation effort (measured as body mass loss) than those exposed to higher winds due to increased effort to warm their clutch (Høyvik Hilde et al., 2016). However, a decrease in winds during periods where there are extreme elevated temperatures may exacerbate incubation effort due to birds exceeding their thermal neutral zones (Fast et al., 2007).

\section{Importance of Taking a Multiple Stressor Approach}

Although individual stressors such as contaminants or climate change are resulting in large shifts in ecosystems, wildlife are currently experiencing these multiple sources of anthropogenic change at a continually increasing rate (Vinebrooke et al., 2004; Munns, 2006). Although we expect individual stressors to have interactive effects, few studies have examined how multiple, cumulative stressors impact key mechanisms at the heart of reproductive performance and fitness (Crain et al., 2008), especially in highly understudied systems such as the Arctic. Compared to single stressors examined in isolation, multiple stressors are expected to contribute to synergistic or additive impacts on organisms, increasing overall vulnerability to environmental change, especially in systems already sensitive to change, such as the Arctic (Vinebrooke et al., 2004; Schindler and Smol, 2006). Importantly, the combined, synergistic effects of these stressors are now expected to be a 'worst-case scenario' for Arctic species (Jenssen, 2006). For example, models combining seasurface temperature as a marker for climate change, predicted reductions in reproductive investment as a result of pollution levels, and predicted predation have suggested that a multiple stressor system with climate change and contaminants is increasingly likely to cause extinctions in Arctic breeding seabirds compared to single stressor scenarios (Bårdsen et al., 2018). However, these interactions are currently poorly understood, and more importantly have not been tested empirically, especially in relation to the indirect effects of contaminants and climate change mediated via the mother's incubation behaviour. As such, empirical investigations examining how multiple simultaneous factors may directly and indirectly impact breeding decisions will be key to understanding how multiple stressors ultimately affect offspring recruitment in long-lived, low fecundity Arctic breeding seabird species (Sandvik and Erikstad, 2008; Bårdsen et al., 2018).

\section{RESEARCH APPROACH}

Our overall goal was to examine the interactive effects of environmental conditions and contaminants on incubation behaviour from early to late stages. For this research project, we are studying the Common Eider (Somateria mollissima) a long-lived, migratory, coloniallynesting seaduck with breeding populations across the circumpolar Arctic (Mosbech et al., 2006; Hennin et al., 2015). Female eiders undergo a 24-26 day incubation fast (Hanssen et al., 2002; Bottitta et al., 2003; Sénéchal et al., 2011), during which time contaminants accumulated in a female's lipid and protein stores, such as organochlorines (Bustnes et al., 2010) and mercury (Wayland et al., 2005), can increase in the blood stream due to mobilization of internal resources. The elevation of contaminants in the blood may potentially interfere with reproductive hormones such as PRL, which can impact incubation decisions (i.e., incubation consistency, willingness to abandon during acute stressors; Tartu et al., 2016). This effect may be amplified due to the environmental conditions a hen is exposed to while incubating (Fast et al., 2007). However, to date the release of mercury has not been studied in incubating females to examine the impacts of mercury on incubation behaviour (Peakall et al., 1980, Kubiak et al., 1989). More importantly, aside from population modelling, none of these contaminants' effects have been looked at within the multiple stressor framework of environmental stressors such as temperature, which may exasperate these effects (Bårdsen et al., 2018).

Common Eider nests at the Mitivik colony (East Bay Island; $64^{\circ} 02^{\prime} \mathrm{N}, 81^{\circ} 47^{\prime} \mathrm{W}$; Fig. 1) were examined from late June to early July in $2018(\mathrm{n}=31)$ and $2019(\mathrm{n}=31)$. We deployed monitoring equipment on each nest, consisting of a trail camera (Browning 2018 Strike Force Pro) placed 1-metre away from the nest cup to collect motion-activated footage and a nest temperature probe (Tinytag ${ }^{\circledR}$ Plus 2 ) in the middle of the clutch from underneath to record nest temperature every minute for the duration of incubation (Figs. 2, 3). Nest temperature provides noninvasive and remotely collected data on the hen's movement on her nest, her incubation behaviour. To collect environmental metrics, 


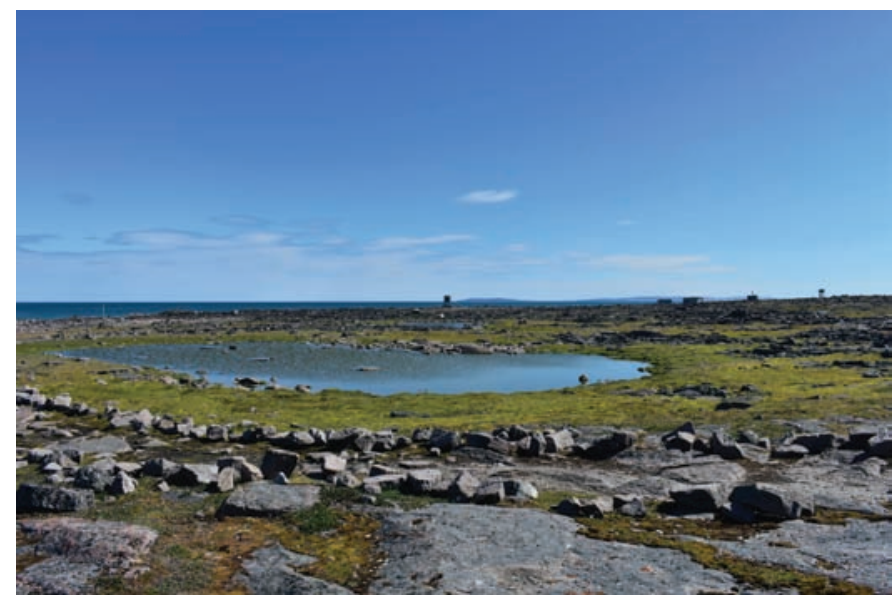

FIG. 1. Common Eiders at the Mitivik (East Bay Island) research station (pictured above on July 2018) were studied in the summers of 2018 and 2019 to help determine the impacts of multiple stressors.

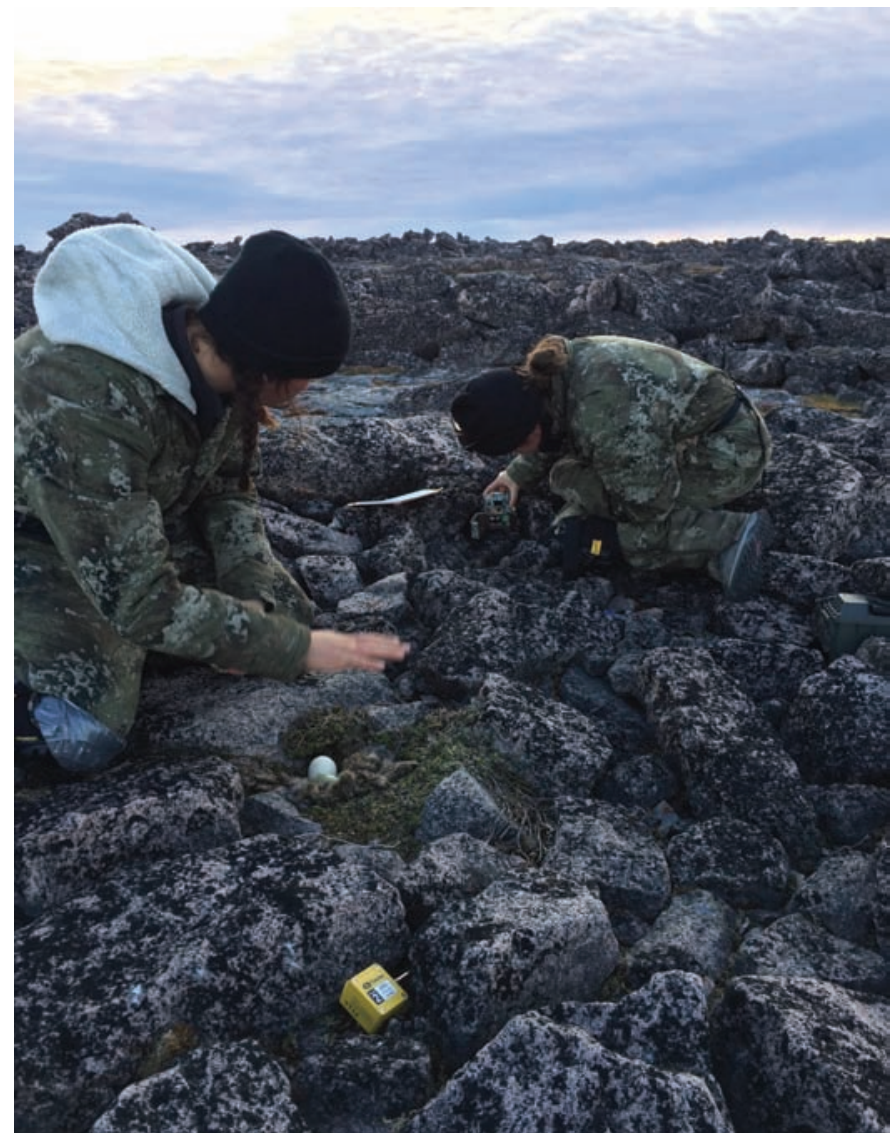

FIG. 2. Graduate students Reyd Smith (left) and Erica Geldart (right) deploying incubation and temperature monitoring equipment on a common eider nest at Mitivik (East Bay Island), Nunavut in June, 2019 (Photo credit: Christophe Boyer).

temperature and light pendants (HOBO Pendant ${ }^{\circledR}$ MX2201 and $64 \mathrm{~K}$ ), we placed $\sim 0.5 \mathrm{~m}$ away at nest level to determine each hen's temperature and sun exposure (amplifies the heat a hen is exposed to; Figs. 2, 3). A total of five Kestrel
5500 weather meters were placed on blinds around Mitivik at approximately $3 \mathrm{~m}$ off the ground to collect general aboveground temperature and wind across the island (Fig. 3). Incubation behaviour over 24-hour periods during early (days 4-7), middle (days 12-15), and late (days 20-23) stages were quantified for each hen, whenever possible, using nest temperature data via Tinytag probes and validated using camera footage data (length of continuous incubation, number of movements on the nest). To quantify the relative amount of mercury a hen may be exposed to in a noninvasive manner, we collected the first laid egg from each nest being monitored and analyzed both the yolk and albumen for total mercury concentrations (Fig. 3). Egg mercury has been shown to be correlated to the amount of mercury in a bird's blood during laying; hence can be used as a proxy for relative mercury levels (Evers et al., 2003; Brasso et al., 2010). Eggs removed were replaced with a common eider egg from a nearby nest to ensure clutch size consistency (Fig. 3). Day of incubation was determined by candling the first-laid egg upon collection to get egg age, therefore lay date.

For this study, we predicted that females with higher egg mercury load that are concurrently faced with increased air temperature exposure and lower winds will have the lowest incubation consistency and that this effect will increase as a female progresses though early to late incubation. Further, we also expect females with a higher mercury load and exposure to elevated air temperatures will have lower breeding success because of earlier predation and nest failure rate.

\section{PRELIMINARY RESULTS}

\section{Incubation Behaviour}

While analysis of incubation behaviour is still underway, results currently show a wide range in individual eider behaviour on the nest. Average stationary time over 24 hours ranges from 37 minutes (low consistency) to 77 minutes (high consistency) with an average of 58 minutes. Movements on the nest over 24 hours, where a hen stands up and shifts position, ranged from 42 (low consistency) to 17 (high consistency), with an average of 24. The large range seen in eider incubation behaviour will allow us to compare how consistent a hen's behaviour is relative to her individual mercury levels and thermal environmental conditions.

\section{Egg Mercury Content}

Preliminary results of egg mercury content show an average for both 2018 and 2019 of $0.068 \mu \mathrm{g} / \mathrm{g}$ dry weight (dw) in yolk (range $0.022-0.191 \mu \mathrm{g} / \mathrm{g} \mathrm{dw}$ ), and $2.041 \mu \mathrm{g} / \mathrm{g}$ $\mathrm{dw}$ in albumen (range 2.041-4.290 $\mu \mathrm{g} / \mathrm{g} \mathrm{dw}$ ). Given eiders have an average egg yolk:albumen ratio of 1:1 (Swennen and Van der Meer, 1995), calculating an egg homogenate 

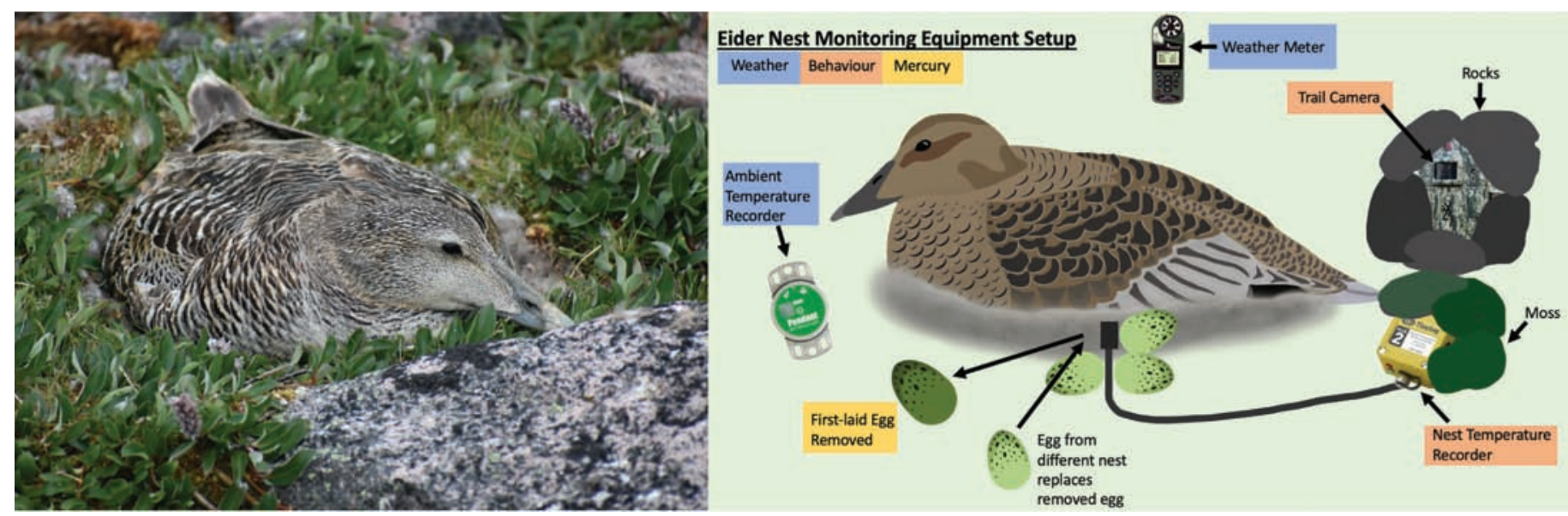

FIG. 3. Incubating Common Eider hen (left) with diagram of incubation and weather monitoring equipment deployed on eider nests (right). Equipment included an ambient temperature recorded (HOBO) and weather meter (Kestrel) to determine temperatures and wind speed, a trail camera (Browning) and nest temperature recorded (Tiny Tag) to gather incubation behaviour, and collection of the first-laid egg, with replacement egg from another nest, to obtain a proxy for hen mercury levels.

from our yolk and albumen results (yolk*0.5+albumen*0.5) show an average of $1.054 \mu \mathrm{g} / \mathrm{g} \mathrm{dw}$ (range $0.313-2.241 \mu \mathrm{g} / \mathrm{g}$ $\mathrm{dw})$. These values are above levels seen previously at this site in $2008(0.501 \mu \mathrm{g} / \mathrm{g} \mathrm{dw}$, range $0.373-0.583$; Akearok et al., 2010) and provide a wide range of eider mercury proxies to compare to incubation behaviour.

\section{Temperature Metrics}

Air temperatures and wind speeds at eider nest level also show a wide variation at both inter- and intra- nest levels. At-nest temperatures determined via $\mathrm{HOBO}$ pendants show a large range in temperatures over 24 hours, using one hen for example showing a range of $0^{\circ} \mathrm{C}$ at night to over $40^{\circ} \mathrm{C}$ during the day, with another hen on the same day ranging from $-1^{\circ} \mathrm{C}$ to $35^{\circ} \mathrm{C}$ at different times of the day due to shading differences (rocks, blinds, natural topography). Temperatures collected from the at-nest HOBOs showed higher temperatures than kestrels collecting weather data, with over $20^{\circ} \mathrm{C}$ difference at the same time due to heat amplification by surrounding rocks and the dark surface of the HOBO, similar to that of the dark eider hen. Thus, the large variation in recorded at-nest and weather temperatures will allow us to compare exposed heat, in combination with relative mercury levels, to a hen's incubation behaviour.

\section{SIGNIFICANCE}

Although we expect these individual stressors, such as mercury and thermal stress, to have significant effects, few studies have examined how multiple, cumulative stressors impact key mechanisms such as behaviours that are at the heart of reproductive performance and fitness (Crain et al., 2008). Compared to single stressors examined in isolation, multiple stressors are expected to contribute to amplified impacts, increasing overall vulnerability to environmental change (Schindler and Smol, 2006). Models combining sea-surface temperature as a marker for climate change, predicted reductions in reproductive investment as a result of pollution, and predation have suggested that the multiple stressor system of climate change, contaminants and predation is increasingly likely to cause extinctions in Arctic-breeding seabirds compared to single stressor scenarios (Bårdsen et al., 2018). However, these interactions are currently poorly understood, and more importantly, have not been tested empirically. As such, empirical investigations examining how simultaneous factors may directly and indirectly impact behaviour will be key to understanding how multiple stressors ultimately affect offspring recruitment in long-lived, low fecundity Arctic breeding seabirds (Bårdsen et al., 2018).

\section{ACKNOWLEDGMENTS}

I am honoured to be the recipient of the Arctic Institute of North America's 2020 Lorraine Allison Memorial Scholarship. First and foremost, I would like to thank the people of Inuit Nunangat, specifically the residents of Salliq (Coral Harbour) and Shugliaq (Southampton Island) within the Kivalliq Region for allowing us to conduct our research at Mitivik, and for their meaningful long-standing collaboration with our research camp.

Thank you to the 2018 and 2019 East Bay field technicians who assisted in sample collection and equipment deployment and retrieval. Thank you as well to the Littoral Environment et Sociétés (La Rochelle Université, LIENSs) for our mercury analysis. We also thank Environment and Climate Change Canada, the Natural Sciences and Engineering Research Council of Canada, Canada Research Chairs Program, the Nunavut Wildlife Management Board, Northern Scientific Training Program, Polar Continental Shelf Project, Polar Knowledge Canada, the Canadian Network of Centres of Excellence (ArcticNet), the American Ornithological Society, 
the Government of Ontario and the University of Windsor for logistical support, research and personal funding. Animal care approval for this project was granted through the University of Windsor Committee for Animal Care (AUPP \#11-06; Reproductive Strategies of Arctic-Breeding Common Eiders) and ECCC Animal Care (EC-PN-15-026).

I am most fortunate to have Dr. Oliver Love as my mentor and MSc supervisor, who has provided me with sincere guidance and support throughout my degree. As well, I have had the great opportunity to work with a wonderful team of researchers who have offered unwavering support and inspiration, including Dr. Grant Gilchrist, Dr. Jennifer Provencher, Dr. Jérôme Fort, Dr. Christina Semeniuk, my friends and colleagues in the Love and Semeniuk labs at the University of Windsor, and my fellow research technicians at East Bay who provided encouragement and endless laughter during the field season.

\section{REFERENCES}

Akearok, J.A., Hebert, C.E., Braune, B.M., and Mallory, M.L. 2010. Inter- and intraclutch variation in egg mercury levels in marine bird species from the Canadian Arctic. Science of the Total Environment 408(4):836-840. https://doi.org/10.1016/j.scitotenv.2009.11.039

Bårdsen, B.J., Hanssen, S.A., and Bustnes, J.O. 2018. Multiple stressors:Modeling the effect of pollution, climate, and predation on viability of a sub-arctic marine bird. Ecosphere 9(7):e02342.

Boening, D.W. 2000. Ecological effects, transport, and fate of mercury:A general review. Chemosphere 40(12):1335-1351. https://doi.org/10.1016/S0045-6535(99)00283-0

Bottitta, G.E., Nol, E., and Gilchrist, H.G. 2003. Effects of experimental manipulation of incubation length on behavior and body mass of Common Eiders in the Canadian Arctic. Waterbirds 26(1):100-107. https://doi.org/10.1675/1524-4695(2003)026[0100:EOEMOI]2. $0 . \mathrm{CO} ; 2$

Brasso, R.L., Abdel Latif, M.K., and Cristol, D.A. 2010. Relationship between laying sequence and mercury concentration in tree swallow eggs. Environmental Toxicology and Chemistry 29:1155-1159.

https://doi.org/10.1002/etc.144

Bustnes, J.O., Bakken, V., Erikstad, K.E., Mehlum, F., and Skaare, J.U. 2001. Patterns of incubation and nest-site attentiveness in relation to organochlorine (PCB) contamination in glaucous gulls. Journal of Applied Ecology 38(4):791 - 801. https://doi.org/10.1046/j.1365-2664.2001.00633.x

Bustnes, J.O., Moe, B., Herzke, D., Hanssen, S.A., Nordstad, T., Sagerup, K., Gabrielsen, G.W., and Borgå, K. 2010. Strongly increasing blood concentrations of lipid-soluble organochlorines in high arctic common eiders during incubation fast. Chemosphere 79(3):320-325. https://doi.org/10.1016/j.chemosphere.2010.01.026
Campbell, L.M., Norstrom, R., Hobson, K.A., Muir, D., Backus, S., and Fisk, A. 2005. Mercury and other trace elements in a pelagic Arctic marine food web (Northwater Polynya, Baffin Bay). Science of the Total Environment 351-352:247-263.

Ceia, F.R., and Ramos, J.A. 2015. Individual specialization in the foraging and feeding strategies of seabirds:A review. Marine. Biology 162(10):1923-1938. https://doi.org/10.1007/s00227-015-2735-4

Colborn, T., Vom Saal, F.S., and Soto, A.M. 1993. Developmental effects of endocrine-disrupting chemicals in wildlife and humans. Environmental Health Perspectives 101(5):378-384. https://doi.org/10.1289/ehp.93101378

Crain, C.M., Kroeker, K., and Halpern, B.S. 2008. Interactive and cumulative effects of multiple human stressors in marine systems. Ecology Letters 11(12):1304-1315.

https://doi.org/10.1111/j.1461-0248.2008.01253.x

Crick, H. 2004. The impact of climate change on birds. Ibis 146(s1):48-56. https://doi.org/10.1111/j.1474-919X.2004.00327.x

Descamps, S., Aars, J., Fuglei, E., Kovacs, K.M., Lydersen, C., Pavlova, O., Pedersen, A.O., Ravolainen, V., and Strom, H. 2017. Climate change impacts on wildlife in a High Arctic archipelago-Svalbard, Norway. Global Change Biology 23(2):490-502.

https://oi.org/10.1111/gcb.13381

DuRant, S.E., Hepp, G.R., Moore, I.T., Hopkins, B.C., and Hopkins, W.A. 2010. Slight differences in incubation temperature affect early growth and stress endocrinology of wood duck (Aix sponsa) ducklings. Journal of Experimental Biology 213(1):45-51. https://doi.org/10.1242/jeb.034488

Dietz, R., Outridge, P., and Hobson, K.A. 2009. Anthropogenic contributions to mercury levels in present-day Arctic animals -A review. Science of the Total Environment 407(24):6120-6131.

https://doi.org/10.1016/j.scitotenv.2009.08.036

Evers, D.C., Taylor, K.M., Major, A., Taylor, R.J., Poppenga, R.H., and Scheuhammer, A.M. 2003. Common loon eggs as indicators of methylmercury availability in North America. Ecotoxicology 12:69-81.

Fast, P.L.F., Gilchrist, H.G., and Clark, R.G. 2007. Experimental evaluation of nest shelter effects on weight loss in incubating common eiders Somateria mollissima. Journal of Avian Biology 38(2):205-213. https://doi.org/10.1111/j.0908-8857.2007.03820.x

Fisher, S.A., Bortolotti, G.R., Fernie, K.J., Bird, D.M., and Smits, J.E. 2006. Behavioral variation and its consequences during incubation for American kestrels exposed to polychlorinated biphenyls. Ecotoxicology and Environmental Safety 63(2):226-235.

https://doi.org/10.1016/j.ecoenv.2005.07.021

Frederiksen, M., Edwards, M., Richarfson, A.J., Halliday, N.C., and Wanless, S. 2006. From plankton to top predators:Bottomup control of a marine food web across four trophic levels. Journal of Animal Ecology 75(6):1259-1268.

https://doi.org/10.1111/j.1365-2656.2006.01148.x 
Hanssen, S., Engebretsen, H., and Erikstad, K. 2002. Incubation start and end size in relation to body reserves in the common eider. Behavioural Ecology and Sociobiology 52(4):282 - 288.

Hayward, T.L. 1997. Pacific Ocean climate change:Atmospheric forcing, ocean circulation and ecosystem response. Trends in Ecology and Evolution 12(4):150-154. https://doi.org/10.1016/S0169-5347(97)01002-1

Hennin, H.L., Legagneux, P., Bêty, J., Williams, T.D., Grant Gilchrist, H., Baker, T.M., and Love, O.P. 2015. Pre-breeding energetic management in a mixed-strategy breeder. Oecologia 177(1):235-243. https://doi.org/10.1007/s00442-014-3145-x

Hoegh-Guldberg, O., and Bruno, J.F. 2010. The impact of climate change on the world's marine ecosystems. Science 328(5985):1523-1528.

https://doi.org/10.1126/science.1189930

Høyvik Hilde, C., Pélabon, C., Guéry, L., Gabrielsen, G.W., and Descamps, S. 2016. Mind the wind:Microclimate effects on incubation effort of an arctic seabird. Ecology and Evolution 6(7):1914-1921. https://doi.org/10.1002/ece3.1988

IPCC (Intergovernmental Panel on Climate Change). 2019:Climate change and land:An IPCC special report on climate change, desertification, land degradation, sustainable land management, food security, and greenhouse gas fluxes in terrestrial ecosystems. Geneva, Switzerland:IPCC https://www.ipcc.ch/srccl/download/

Iverson, S.A., Grant Gilchrist, H., Smith, P.A., Gaston, A.J., and Forbes, M.R. 2014. Longer ice-free seasons increase the risk of nest depredation by polar bears for colonial breeding birds in the Canadian Arctic. Proceedings of the Royal Society B:Biological Sciences 281(1779):20133128. https://doi.org/10.1098/rspb.2013.3128

Jæger, I., Hop, H., and Gabrielsen, G.W. 2009. Biomagnification of mercury in selected species from an Arctic marine food web in Svalbard. Science of the Total Environment 407(16):4744-4751.

https://doi.org/10.1016/j.scitotenv.2009.04.004

Jenssen, B.M. 2006. Endocrine-disrupting chemicals and climate change:A worst-case combination for Arctic marine mammals and seabirds? Environmental Health Perspectives 114(1):76-80. https://doi.org/10.1111/j.1474-919X.2004.00327.x

Johannessen, O.M., Bengtsson, L., Miles, M.W., Kuzmina, S.I., Semenov, V.A., Alekseev, G.V., Nagurnyi, A.P. et al. 2004. Arctic climate change:Observed and modelled temperature and sea-ice variability. Tellus, Series A:Dynamic Meteorology and Oceanography 56(4):328-341.

https://doi.org/10.1111/j.1600-0870.2004.00060.x

Kubiak, T.J., Harris, H.J., Smith, L.M., Schwartz, T.R., Stalling, D.L., Trick, J.A., Sileo, L., Docherty, D.E., Erdman, T.C. 1989. Microcontaminants and reproductive impairment of the Forster's Tern on Green Bay, Lake Michigan. Archives of Environmental Contamination and Toxicology 18:706-727.
Liu, G., Cai, Y., O’Driscoll, N., Feng, X., and Jiang, G. 2012. Overview of mercury in the environment. In: Liu, G., Cai, Y., and O'Driscoll, N., eds. Environmental Chemistry and Toxicology of Mercury. Wiley, Hoboken, New Jersey. 1-12.

Macdonald, R.W., Barrie, L.A., Bidleman, T.F., Diamond, M.L., Gregor, D.J., Semkin, R.G., Strachan, W.M.J., et al. 2000. Contaminants in the Canadian Arctic:5 years of progress in understanding sources, occurrence and pathways. Science of the Total Environment 254(2-3):93-234.

https://doi.org/10.1016/S0048-9697(00)00434-4

Martin, K., and Wiebe, K.L. 2004. Coping mechanisms of alpine and arctic breeding birds:Extreme weather and limitations to reproductive resilience. Integrative and Comparative Biology 44(2):177- 185 .

https://doi.org/10.1093/icb/44.2.177

Martin, K., and Camfield, A.F. 2009. The influence of ambient temperature on horned lark incubation behaviour in an alpine environment. Behaviour 146(12):1615 - 1633. https://doi.org/10.1163/156853909X463335

Meehl, G.A., Zwiers, F., Evans, J., Knutson, T., Mearns, L., and Whetton, P. 2000. Trends in extreme weather and climate events:Issues related to modeling extremes in projections of future climate change. Bulletin of the American Meteorological Society 81(3):427-436.

https://doi.org/10.1175/1520-0477(2000)081<0427:TIEWAC $>2$. 3.CO;2

Mosbech, A., Grant Gilchrist, H., Merkel, F., Sonne, C., Flagstad, A., and Nyegaard, H. 2006. Year-round movements of Northern Common Eiders Somateria mollissima borealis breeding in Arctic Canada and West Greenland followed by satellite telemetry. Ardea 94(3):651 - 665.

Muir, D.C.G., Wagemann, R., Hargrave, B.T., Thomas, D.J., Peakall, D.B., and Norstrom, R.J. 1992. Arctic marine ecosystem contamination. Science of the Total Environment 122(1-2):75-134.

Munns, W.R. 2006. Assessing risks to wildlife populations from multiple stressors:Overview of the problem and research needs. Ecology and Society 11(1):23.

Nord, A., and Nilsson, J.A. 2011. Incubation temperature affects growth and energy metabolism in blue tit nestlings. The American Naturalist 178(5):639-651.

https://doi.org/10.1086/662172

Ottinger, M.A., Bohannon, M., Carpenter, L., Carro, T., Rochester, J.R., and Dean, K.M. 2015. Actions of toxicants and endocrinedisrupting chemicals in birds. Sturkie's Avian Physiology,6th edition. 979-1001. https://doi.org/10.1016/B978-0-12-407160-5.00041-5

Peakall, D.B., Fox, G.A., Gilman, A.P., Hallett, D.J., and Norstron, R.J. 1980. Reproductive success of Herring Gulls as an indicator of Great Lakes water quality. Hydrocarbons and Halogenated Hydrocarbons in the Aquatic Environment. 337344.

Pörtner, H.O., and Peck, M.A. 2010. Climate change effects on fishes and fisheries:Towards a cause-and-effect understanding. Journal of Fish Biology 77(8):1745 - 1779.

https://doi.org/10.1111/j.1095-8649.2010.02783.x 
Pratte, I., Tomlik, M.D., Betsch, T.A., Braune, B.M., Milton, G.R., and Mallory, M.L. 2015. Trace elements in eggs of common eiders (Somateria mollissima) breeding in Nova Scotia, Canada. Marine Pollution Bulletin 100(1):586-591. https://doi.org/10.1016/j.marpolbul.2015.08.004

Prop, J., Aars, J., Bårdsen, B.-J., Hanssen, S.A., Bech, C., Bourgeon, S., de Fouw, J., et al. 2015. Climate change and the increasing impact of polar bears on bird populations. Frontiers in Ecology and Evolution 3(33):1-12.

Sandvik, H., and Erikstad, E.K. 2008. Seabird life histories and climatic fluctuations:A phylogenetic-comparative time series analysis of North Atlantic seabirds. Ecography 31(1):73-83. https://doi.org/10.1111/j.2007.0906-7590.05090.x

Scavia, D., Field, J.C., Boesch, D.F., Buddemeier, R.W., Burkett, V., Cayan, D.R., Fogarty, M., et al. 2002. Climate change impacts on U.S. coastal and marine ecosystems. Estuaries 25:149-164.

https://doi.org/10.1007/BF02691304

Schindler, D.W., and Smol, J.P. 2006. Cumulative effects of climate warming and other human activities on freshwaters of Arctic and subarctic North America. AMBIO:A Journal of the Human Environment 35(4):160-168. https://doi.org/10.1579/0044-7447(2006)35[160:CEOCWA]2.0. $\mathrm{CO} ; 2$

Seewagen, C.L. 2010. Threats of environmental mercury to birds:Knowledge gaps and priorities for future research. Bird Conservation International 20(2):112-123. https://doi.org/10.1017/S095927090999030x

Sénéchal, É., Bêty, J., Grant Gilchrist, H., Hobson, K.A., and Jamieson, S.E. 2011. Do purely capital layers exist among flying birds? Evidence of exogenous contribution to arcticnesting common eider eggs. Oecologia 165(3):593-604. https://doi.org/10.1007/s00442-010-1853-4

Serreze, M.C., and Barry, R.G. 2011. Processes and impacts of Arctic amplification: A research synthesis. Global and Planetary Change 77(1-2):85-96. https://doi.org/10.1016/j.gloplacha.2011.03.004

Serreze, M.C., and Meier, W.N. 2018. The Arctic's sea ice cover: Trends, variability, predictability, and comparisons to the Antarctic. Annals of the New York Academy of Sciences 1436(1):36-53. https://doi:10.1111/nyas.13856

Smith, P.A., Elliot, K.H., Gaston, A.J., Grant Gilchrist, H. 2010. Has early ice clearance increased predation on breeding birds by polar bears? Polar Biology 33(8):1149-1153.

Stempniewicz, L., Błachowiak-Samołyk, K., and Wesławski, J.M. 2007. Impact of climate change on zooplankton communities, seabird populations and arctic terrestrial ecosystem-A scenario. Deep-Sea Research Part II:Topical Studies in Oceanography 54(23-26):2934-2945.
Swennen, C., and Van der Meer, J. 1995. Composition of eggs of common eiders. Canadian Journal of Zoology 73(3):584 -588. https://doi.org/10.1139/z95-067

Tartu, S., Goutte, A., Bustamante, P., Angelier, F., Moe, B., Clément-Chastel, C., Bech, C., Gabrielsen, G.W., Bustnes, J.O., and Chastel, O. 2013. To breed or not to breed:Endocrine response to mercury contamination by an Arctic seabird. Biology Letters 9(4):20130317. https://doi.org/10.1098/rsbl.2013.0317

Tartu, S., Bustamante, P., Angelier, F., Lendvai, Á.Z., Moe, B., Blévin, P., Bech, C., Gabrielsen, G.W., Bustnes, J.O., and Chastel, O. 2016. Mercury exposure, stress and prolactin secretion in an Arctic seabird:An experimental study. Functional Ecology 30(4):596-604.

https://doi.org/10.1111/1365-2435.12534

Vinebrooke, R.D., Cottingham, K.L., Norberg, J., Scheffer, M., Dodson, S.I., Maberly, S.C., and Sommer, U. 2004. Impacts of multiple stressors on biodiversity and ecosystem functioning:The role of species co-tolerance. Oikos 104:451-457.

Visser, M.E., Holleman, L.J.M., and Caro, S.P. 2009. Temperature has a causal effect on avian timing of reproduction. Proceeds of the Royal Society of London B:Biological Sciences 276(1665):20090213

Wayland, M., Grant Gilchrist, H., and Neugebauer, E. 2005. Concentrations of cadmium, mercury and selenium in common eider ducks in the eastern Canadian arctic:Influence of reproductive stage. Science of the Total Environment $351-352: 323-332$. https://doi.org/10.1016/j.scitotenv.2005.03.033

Wiener, J., Krabbenhoft, D., Heinz, G., and Scheuhammer, A.M. 2003. Ecotoxicology of mercury. In:Hoffman, D.J., Rattner, B.A., Burton, G.A.J., and Cairns, J.J., eds. Handbook of Ecotoxicology. New York:CRC Press. 409-463.

Zhang, L., Wang, S., Wang, L., Wu, Y., Duan, L., Wu, Q., Wang, F., et al. 2015. Updated Emission Inventories for Speciated Atmospheric Mercury from Anthropogenic Sources in China. Environmental Science and Technology 49(5):3185-3194.

Zhang, Y., Jacob, D.J., Horowitz, H.M., Chen, L., Amos, H.M., Krabbenhoft, D.P., Slemr, F., St. Louis, V.L., and Sunderland, E.M. 2016. Observed decrease in atmospheric mercury explained by global decline in anthropogenic emissions. Proceeds of the National Academy of Science of the United States of America 113(3):526-531.

Reyd Smith is the recipient of the Lorraine Allison Scholarship. She is currently a Master of Science student in the Department of Integrative Biology at the University of Windsor. smith1ax@uwindsor.ca 